\title{
Biodiversity policies, opportunities for restoring the economy
}

\author{
Nicoleta-Nona Ardeleanu1 ${ }^{1}$, Iuliana-Gabriela Breabăn² \\ 1 "Alexandru Ioan Cuza" University, Faculty of Geography and Geology, Iași; \\ ardeleanunonanic@gmail.com \\ 2 "Alexandru Ioan Cuza" University, Faculty of Geography and Geology, Iași; \\ iulianab2001@gmail.com \\ * Correspondence: ardeleanunonanic@gmail.com
}

Keywords: Biodiversity Strategy, Natura 2000, ecosystem approach, economic impact

\begin{abstract}
The purpose of this paper is to analyze the strategic and legal framework of the various areas directly dependent on the protection of biodiversity and the ecosystem approach in the funding programmes related to them. Data were collected by consulting a variety of sources, including articles, project results, European and national legislation, strategies and funding programs in the fields of Water, Forestry, Biodiversity, Climate Change, Fisheries and Aquaculture, Agriculture and Rural Development, Energy and Regional Development. The results showed that, in the areas analyzed, there are no efficient tools for the integration of ecosystem services and natural capital. The level of integration of the ecosystem approach in the analyzed areas compared to the state of ecosystems in Romania indicates that there are not enough measures to protect natural capital through sustainable management. Both inter-institutional integration and coordination are needed to streamline the management of natural capital and the correct analysis and implementation of a payment system for ecosystem services.
\end{abstract}

\section{Introduction}

Biodiversity is essential for life. Our planet and the economy depend on it. When nature is healthy, it protects and provides ecosystem benefits and services that support human health.

Biodiversity and ecosystems provide us with food, materials, recreation, and wellbeing. Biodiversity has an important role in the life of society, being reflected in their culture and spirituality (art, literature and traditions) as well and practices of land use and resources and the like.

Unsustainable human activities lead to the loss of biodiversity and the intensification of climate change, both of which are interdependent and mutually influential. This has a boomerang effect, as evidenced by the recent pandemic caused by the Covid-19 virus (EU Biodiversity Strategy for 2030).

The construction, agriculture and food sectors are all highly dependent on nature and industries like chemicals, aviation, travel and tourism, real supply chain and transport, consumer goods and lifestyle depend through their supply chain on nature.

In this sense, the strategies established at European level, those at national level, national legislation transposing European directives in the field of biodiversity protection create the legal framework that can connect economically important sectors to biodiversity protection through financial instruments to support and promote sustainable exploitation of natural capital. 


\subsection{Strategic documents on biodiversity conservation}

The EU Strategy for Biodiversity to $\mathbf{2 0 2 0}$, adopted by the European Commission in 2011 to combat the loss of biodiversity and ecosystem services by 2020, to achieve Objective 2 Member States will "map and assess ecosystem services, assess the state of ecosystems and services in their national territory by 2014, assess the economic value of such services and promote the integration of these values into national accounting and reporting systems by 2020 "(MAES et al., 2014) and Action 7" Assessing the impact of EU funds on biodiversity and setting compensation opportunities ".

The Progress Report at mid-term (2015) on the progress made in meeting the objectives and actions set out in the strategy highlights the five key threats to biodiversity identified: habitat change, pollution, overexploitation, invasive species, climate change continues to put pressure on biodiversity.

For the Objective no. 2, no progress has been made and ecosystem degradation has continued, there have been no firm commitments to restore ecosystems, investment in restoration and green infrastructure has been insufficient.

The new EU Biodiversity Strategy for 2030, entitled "Bringing nature back to our lives", adopted on $20^{\text {th }}$ of May 2020, sets ambitious targets:

- Establishing protected areas for at least 30\% of land in Europe, 30\% of sea in Europe

- Restoring degraded ecosystems at land and sea across the whole of Europe by increasing organic farming and biodiversity, rich landscape features on agricultural land, halting and reversing the decline of pollinators, reducing the use and harmfulness of pesticides by $50 \%$ by 2030 , restoring at least $25,000 \mathrm{~km}$ of EU rivers to a free-flowing state, planting 3 billion trees by 2030

- Unlocking $€ 20$ billion per year for biodiversity through various sources, including EU funds and national and private funding. Natural capital and biodiversity considerations will be integrated into business practices

- Making the EU a world leader in addressing the global biodiversity crisis. The Commission will help to build a "European Business for Biodiversity" movement and will pay particular attention to measures to stimulate and remove barriers to the adoption of nature-based solutions, as they can lead to significant business and employment opportunities in various sectors. Investments in biodiversity will be supported; methods, criteria and standards will be developed to describe the essential characteristics of biodiversity, its services, values and sustainable use.

In Romania, the National Strategy and the Action Plan for biodiversity conservation 2014-2020 were approved by Decision no. 1081/2013, with the main targets: halting the loss of biodiversity and restoring degraded ecosystems; integrating biodiversity conservation into sectoral policies; promoting innovative methods and practices, as well as green technology for biodiversity conservation to support sustainable development. In order to achieve these objectives, the following strategic lines have been established:

- Development of the general legal and institutional framework and provision of financial resources;

- Ensuring the coherence and efficient management of the national network of protected areas;

- Ensuring a favorable conservation status for protected wildlife species;

- Sustainable use of biological diversity components.

At the same time, the operational objectives set for the integrated management of certain sectors include:

- integrating biodiversity conservation into these sectoral policies;

- reducing the impact of road transport on the environment; 
- application of environmental impact assessment procedures in these sectors.

The results of the implementation are integrated in the trend registered at European level. Thus, although the area of naturally protected areas has increased, no significant progress has been made on the conservation of species and habitats, threats to ecosystems and the services they provide persist, and many pressures are increasing.

\section{Materials and Methods}

Sustainable use of biodiversity components requires an ecosystem approach to integrated resource management and the integration of biodiversity conservation priorities into sectoral policies and strategies, as reflected in funding programs.

This paper assesses the degree of integration of the ecosystem approach in the funding programs developed for the period 2014-2020, for the fields of Water, Forestry, Biodiversity, Climate Change, Fisheries and Aquaculture, Agriculture and Rural Development, Energy, Regional Development. Eligible projects duration in these programs cannot exceed 31.12.2023. The programming documents were consulted and the official data published on the website of the managing authorities were used.

For the Water field, the National Basin Management Plan (PMB) does not specifically mention the term "ecosystem services", but takes over the main objective of the Water Framework Directive, namely to ensure water resources in terms of quality and quantity. Important ecosystem services are provided by freshwater ecosystems. Use of financial allocations under the Large Infrastructure Operational Program (POIM) for the collection and treatment of urban wastewater, as well as the degree of ensuring the drinking water supply of the population and reducing the effects and damages on the population caused by natural phenomena associated with major risks accentuated by climate change, mainly by floods and coastal erosion, they seek to meet the needs identified in the PMB. The Large Infrastructure Operational Program (POIM) 2014-2020 benefits from a financial allocation of approx. 10.17 billion euros. Table 1 present the updated data on the state of absorption of European funds, published by the Ministry of European funds, in the field of water, were a number of 103 projects were contracted worth $33,025,816,243$ lei out of the general total of $92,728,992,550$ lei.

Table 1. Projects approved in Water field

\begin{tabular}{ccc}
\hline POIM & $\begin{array}{c}\text { No. of } \\
\text { projects }\end{array}$ & $\begin{array}{c}\text { Eligible value of } \\
\text { the project (LEI) }\end{array}$ \\
\hline Water field & 103 & 33.025 .816 .243 \\
Total POIM & 652 & 92.728 .992 .550 \\
\hline
\end{tabular}

The system of contributions refers to administrative and infrastructure services for water; therefore it only indirectly recognizes ecosystem service. There are no methods for defining and evaluating water-related ecosystem services, no legal framework for their applicability.

For the Forestry field, Romania does not have a National Strategy for the forestry sector with objectives, measures and deadlines. But many forests belonging to the national forest fund are FSC (responsible forest management) certified, a system that provides for the implementation of a certified forest management as well as the identification, mapping and assurance of forest biodiversity. Articles 11 and 15 of the Forestry Code provide for compensatory payments and payments for ecosystem services, but no implementation methodology has been formally adopted. The National Program for Rural Development 2014-2020 (PNDR) provides funding for a forest-environment measure, as well as a measure for the first afforestation, both meant to have a positive impact on the 
maintenance of forest ecosystems. Table 2 present the updated data regarding projects approved for a forest-environment measure.

Table 2. Projects approved in Forestry field

\begin{tabular}{|c|c|c|c|c|c|}
\hline \multirow[t]{2}{*}{ Sub-measure } & \multirow{2}{*}{$\begin{array}{c}\text { Public } \\
\text { allocation } \\
\text { PNDR } \\
\text { 2014-2020 } \\
\text { v.13.0 }\end{array}$} & \multicolumn{2}{|c|}{$\begin{array}{l}\text { Selected funding } \\
\text { applications }\end{array}$} & \multicolumn{2}{|c|}{$\begin{array}{l}\text { Contracts / Financing } \\
\text { decisions (ongoing and } \\
\text { completed) }\end{array}$} \\
\hline & & No. & Value(lei) & No. & Value(lei) \\
\hline $\begin{array}{c}\text { Sub-measure } 15.1 \\
\text { Payments for } \\
\text { forestry, } \\
\text { environmental and } \\
\text { climate } \\
\text { commitments }\end{array}$ & 115.147 .754 & 922 & 141.485 .341 & 627 & 96.423 .374 \\
\hline $\begin{array}{l}\text { Sub-measure } 8.1 \text { Aid } \\
\text { for reforestation / } \\
\text { creation of woodland } \\
\text { areas }\end{array}$ & 21.786 .653 & 114 & 21.437 .450 & 81 & 14.085 .936 \\
\hline Total & 136.934 .407 & 1.036 & 162.922 .791 & 708 & 110.509 .310 \\
\hline
\end{tabular}

For the field of Biodiversity, the Biodiversity Action Plan stipulates that funding from the state budget and the European Agricultural Fund for Rural Development (EAFRD) must be used for: management of protected natural areas, compensation for forest and land users that respect the management restriction for Natura 2000 sites and compensation for forest users who comply with the restrictions on the exploitation of forests with protection functions of national interest (T1 and T2 category forests). At this point through EAFRD there are no compensation, but there is a state aid scheme aimed at granting compensation representing the value of products that the owners do not harvest, due to the protection functions established by forestry arrangements that cause restrictions in the harvesting of timber. The maximum total value related to the scheme for the period 2017-2020 is 285 million lei. Also through POIM 2014-2020, Priority Axis 4 are financed measures related to biodiversity conservation, air quality monitoring and decontamination of historically polluted sites. Table 3 present the updated data regarding projects approved related to biodiversity conservation.

Table 3. Projects approved in Biodiversity field

\begin{tabular}{ccc}
\hline POIM & $\begin{array}{c}\text { No. of } \\
\text { projects }\end{array}$ & $\begin{array}{c}\text { Eligible value } \\
\text { of the project } \\
\text { (LEI) }\end{array}$ \\
\hline $\begin{array}{c}\text { Biodiversity } \\
\text { field }\end{array}$ & 78 & $756.698 .634,68$ \\
Total POIM & 652 & 92.728 .992 .550 \\
\hline
\end{tabular}

A functional compensation system is not yet implemented. The fact that biodiversity is essential for the provision of ecosystem services used by humans and society is directly mentioned in the following actions: bio-physical assessment and economic exploitation of the components of biodiversity and ecosystem services; elaboration and implementation of methodologies that take into account the value of biodiversity in the cost-benefit analysis for feasibility studies and business plans; integrating the ecosystem approach into the National Strategy for Research, Development and Innovation.

For the field of Climate Change, the National Strategy for Climate Change mentions the capacity of Romania's forests to store carbon and the fact that aquatic ecosystems in forest habitats (e.g. meadows along river sectors, lakes, ponds, peat bogs, swamps) deliver goods and ecosystem services that are important in forest ecology. However, no 
exact reference is made to human well-being, although it mentions "the assessment of ecosystem services and the implementation of an ecosystem approach in decision-making". Green Certificates are provided for in national legislation to encourage the production of energy from renewable sources (solar, wind, hydro and geothermal), but the conditions for biodiversity conservation are not included in the risk of negative impact on the potential of ecosystems to adapt to climate change.

For the Fisheries and Aquaculture field, ecosystem services are mentioned only in the case of aquaculture, but are not fully listed. Improving production capacity is specifically mentioned. The economic importance of aquaculture is recognized, as well as the diversification of activities (especially at the level of the local community). Thus, ecosystem services are indirectly recognized as welfare supporters. The Operational Program for Fisheries and Maritime Affairs (POPAM) includes a measure to improve the aquatic environment, which provides an opportunity to integrate the delivery of ecosystem services, e.g. water quality and quantity. There is no clear and approved methodology for identifying, maintaining and managing ecosystem services. Table 4 present the updated data regarding projects approved under Measure II.10 Aquaculture providing environmental services.

Table 4. Projects approved in Fisheries and Aquaculture field

\begin{tabular}{ccc}
\hline & \multicolumn{2}{c}{ Contracted projects } \\
\cline { 2 - 3 } Call & No. of projects & Eligible value of the project (LEI) \\
\hline 1 & 21 & 69.830 .694 \\
2 & 16 & 31.328 .014 \\
3 & 8 & 14.557 .930 \\
Total & 45 & 115.716 .638 \\
\hline
\end{tabular}

For the field of Agriculture and Rural Development, the National Program for Rural Development (PNDR) recognizes that Agricultural Lands with High Natural Value provide ecosystem services to society and thus, the conservation of these ecosystems provides environmental and socio-economic benefits. Furthermore, the aim is to encourage the environmental objectives of organic farming, such as the maintenance of biodiversity and ecosystems, as well as the protection of soil and water resources. Organic farming is not treated differently in terms of small-scale agriculture compared to large-scale agriculture, which clearly has different effects on the ecosystem.

For agricultural practices beneficial for the climate and the environment, a direct payment scheme within the 2014-2020 programming period is applied, within the PNDR being compensated for the conservation of species and habitats typical of High Natural Value Agricultural Lands, for the stimulation of ecological agriculture, for areas faced with natural constraints or other specific constraints. Table 5 present the updated data regarding payments made under Measures 10,11 and 13 financed by PNDR.

Table 5. Payments made under Measures 10, 11 and 13 financed by PNDR

\begin{tabular}{ccc}
\hline Sub-measure & $\begin{array}{c}\text { Public allocation } \\
\text { PNDR 2014-2020 } \\
\text { V.13.0 }\end{array}$ & $\begin{array}{c}\text { Payments } \\
\text { made }\end{array}$ \\
\hline Measure 10 "Agri-environment and climate" & 977.379 .976 & 563.420 .296 \\
Measure 11 "Organic farming" & 376.703 .660 & 239.346 .728 \\
Measure 13 "Payments for areas facing natural or & 2.182 .843 .140 & 1.519 .164 .093 \\
other specific constraints" & 3.536 .926 .776 & 2.321 .931 .116 \\
\hline Total & & \\
\hline
\end{tabular}


The concept of Natura 2000 is not integrated, although the Rural Development Regulation provides articles to achieve the objectives related to Natura 2000 (conservation of habitats and species) and ecological reconstruction of wetlands. PNDR did not include any of these opportunities.

For the Energy field, the main goal of the Energy Strategy for Romania for the period 2011-2020 is to produce energy based on the need to ensure security of energy supply, sustainable development and competitiveness with an emphasis on improving energy efficiency and promoting renewable energy sources. There is no reference in the Strategy to ecosystem services potentially affected by the development of the energy sector. The financial instruments included in the Energy Strategy for Romania for the period 2011-2020 are:

- Green Certificates;

- Certificates for GHG emissions;

- The Romanian market and the related platform for trading Green Certificates and Certificates. Green certificates focus on reducing pollution, but do not provide for the protection of biodiversity against the exploitation of renewable energy sources.

For the Regional Development field, the Regional Operational Program (ROP) 2014-2020 aims to improve the economic competitiveness and living conditions of regional and local communities by supporting business development (especially small and medium-sized enterprises involved in agriculture, fisheries and aquaculture), infrastructure and services to ensure the sustainable development of the regions; the latter must be able to manage resources efficiently and protect the environment, use their innovative potential and integrate technological progress. Although sustainable development is mentioned, no reference is made to resource limits. Also, the concept of ecosystem management as a fundamental condition for socio-economic development is not integrated. Instead, attention is paid to protecting resources and preventing the impact on environmental pollution. In conclusion, ecosystem services are not explicitly mentioned, but only indirectly refer to the reduction of carbon emissions.

The financial instruments identified for investments are through the Regional Operational Program 2014-2020 (POR), through Priority Axis 3 - Supporting the transition to a low-carbon economy and Priority Axis 4: Supporting sustainable urban development. Table 6 present updated data regarding projects approved under Priority Axis 3 and 4.

Table 6. Projects approved in Regional Development field

\begin{tabular}{ccc}
\hline Priority Axis & $\begin{array}{c}\text { No. of } \\
\text { projects }\end{array}$ & Total value of the project \\
\hline 3 & 833 & 7.703 .444 .552 \\
4 & 130 & 11.061 .389 .758 \\
Total & 963 & 18.764 .834 .309 \\
\hline
\end{tabular}

Ecosystem services are not yet integrated into the Environmental Impact Assessment (EIA) and Strategic Impact Assessment (SEA) procedures.

\section{Results}

\subsection{Ecosystem approach at the operational level}

According to the available data on the state of ecosystems in Romania, the habitats of peatlands, swamps and ponds have a poor state of conservation, rivers have a good and moderate ecological status, but the conservation status of fish species has worsened, $14 \%$ of forests have a poor, unfavourable conservation status, and $41 \%$ have an unfavourable, inadequate conservation status. 
Romania adopted in 2008 the National Sustainable Development Strategy (NDS) 2013-2020-2030 where reference is made to all forms of natural, physical, human and social capital, but also to sustainable growth.

The ecosystem approach at operational level in the analysed fields is presented in table 7.

Table 7. The ecosystem approach

\begin{tabular}{|c|c|c|c|c|}
\hline \multirow[b]{2}{*}{ Field } & \multicolumn{4}{|c|}{ Ecosystem approach at the operational level } \\
\hline & $\begin{array}{l}\text { There are } \\
\text { dedicated tools } \\
\text { for addressing } \\
\text { ecosystem } \\
\text { services and } \\
\text { natural capital }\end{array}$ & $\begin{array}{l}\text { There are some } \\
\text { tools that } \\
\text { proactively } \\
\text { address / build } \\
\text { understanding } \\
\text { of ecosystem } \\
\text { services and } \\
\text { natural capital } \\
\text { within the } \\
\text { policy area. }\end{array}$ & $\begin{array}{l}\text { There are no } \\
\text { dedicated tools } \\
\text { to address } \\
\text { ecosystem } \\
\text { services and } \\
\text { natural capital } \\
\text { directly. }\end{array}$ & $\begin{array}{l}\text { There are no } \\
\text { tools } \\
\text { address } \\
\text { ecosystem } \\
\text { services and } \\
\text { natural capital } \\
\text { in any way. }\end{array}$ \\
\hline Water & & & $\mathrm{X}$ & \\
\hline Forestry & & $x$ & & \\
\hline Biodiversity & & & $x$ & \\
\hline $\begin{array}{l}\text { Climate } \\
\text { Change }\end{array}$ & & $\mathrm{x}$ & & \\
\hline $\begin{array}{l}\text { Fishing and } \\
\text { aquaculture }\end{array}$ & & $\mathrm{x}$ & & \\
\hline $\begin{array}{l}\text { Agriculture and } \\
\text { rural } \\
\text { development }\end{array}$ & & $x$ & & \\
\hline Energy & & & & $x$ \\
\hline $\begin{array}{l}\text { Regional } \\
\text { Develonment }\end{array}$ & & & $x$ & \\
\hline
\end{tabular}

\subsection{Opportunities for restoring the economy}

The analysis of the financing programs and the number of projects financed by biodiversity protection shows that significant amounts have been allocated to these types of projects. Table 8 present the eligible value of the project related to biodiversity protection.

Table 8. The eligible value of the project related to biodiversity protection

\begin{tabular}{cc} 
Projects approved & $\begin{array}{c}\text { Eligible value of the project } \\
\text { (LEI) }\end{array}$ \\
Water and Biodiversity field & 33.782 .514 .878 \\
Projects approved in Forestry field & 110.509 .310 \\
Projects approved in Fisheries and Aquaculture field & 115.716 .638 \\
Payments made under Measures 10, 11 and 13 financed by & \\
PNDR & 2.321 .931 .116 \\
Projects approved in Regional Development field & 18.764 .834 .309 \\
Total & 55.095 .506 .251 \\
\hline
\end{tabular}

\section{Discussion}

Among the areas analyzed, there are no dedicated tools for addressing ecosystem services and natural capital.

For four areas there are some tools that proactively address / build the ecosystem approach, such as forestry, climate change, fisheries and aquaculture, agriculture and rural development. 
For three of the areas there are no dedicated tools that directly address ecosystem services and natural capital. Only certain aspects, often related to the avoidance of negative impacts on (some) ecosystem services are integrated in the sectorial instruments, these being water, regional development, biodiversity.

There are no tools for the energy sector to address ecosystem services and natural capital in any way.

On the other hand, the value of approved projects being implemented or completed that are related to biodiversity protection is important.

Thus, the principles of sustainable use of natural resources and preventive action in these types of projects are correlated with the protection of biodiversity conservation and ecosystems specific to the natural biogeographic framework. The value and number of approved projects suggest an increased awareness in the quality of human life is related to the protection of biodiversity

The analysis of the projects indicates that the selected operations promote investment to ensure compliance with national and European legislation. However, at the national level, there is no significant improvement in biodiversity.

Correlating programs and introducing specific indicators for ecosystem services could lead to increased project effectiveness.

\section{Conclusions}

Currently, Romania uses in one year more resources than its own ecosystems can generate at the same time. Statistically, at the level of 2017, Romania had a biocapacity of $3.1 \mathrm{gh}$ (global hectares) and an ecological footprint of $3.4 \mathrm{gh}$, with a deficit of $0.3 \mathrm{gh}$.

Biodiversity conservation must be seen as complementary to development.

Knowing and respecting environmental limits, as well as maintaining the resilience of ecosystems, are key to ensuring the long-term well-being of citizens.

Innovative tools such as payments for ecosystem services should be properly analyzed and implemented.

In the sectoral policies, the financing programs analyzed, there are no dedicated tools for addressing ecosystem services and natural capital. Inter-institutional integration and coordination is needed to streamline natural capital management.

\section{References}

1. Adamescu M., Cazacu C., et al. Ghid metodologic pentru evaluarea rapidă a serviciilor ecosistemice în ariile protejate din România, realizat în cadrul proiectului: Evaluarea serviciilor ecosistemice ale ariilor protejate în România - Value Eco Serv, 2016, (http://valueecoserv.cndd.ro)

2. Ellis E. C., Pascual U., Mertz O. Ecosystem services and nature's contribution to people: negotiating diverse values and trade-offs in land systems. Current Opinion in Environmental Sustainability, 2019, 38:86-94. https://doi.org/10.1016/j.cosust.2019.05.001

3. Bodescu F., Badea A. et al. Evaluarea ecosistemelor și a serviciilor ecosistemice din România, ghid în cadrul proiectului "Demonstrarea şi promovarea valorilor naturale, pentru a sprijini procesul decizional în România - Natura în Deciziile publice (N4D)" (2018):

4. Bodescu F., Gheorghiu C., Stoian R., et al. Evaluarea ecosistemelor și a serviciilor ecosistemice din România. 2017, 978-606-8038-21-6

5. Bromley, Daniel W. 1990. 'The ideology of efficiency: searching for a theory of policy analysis', Journal of environmental economics and management, 19: 86-107 https://doi.org/10.1016/0095-0696(90)90062-4

6. Bunse, Lukas, Olivia Rendon, and Sandra Luque. 2015. 'What can deliberative approaches bring to the monetary valuation of ecosystem services? A literature review', Ecosystem Services, 14: 88-97 https://doi.org/10.1016/j.ecoser.2015.05.004 
7. Olander L., Johnston R. J., Tallis H., Kagan J., Maguire L. A., Stephen P., Urban D., Boyd J., Lisa W., and Palmer M. Benefit relevant indicators: Ecosystem services measures that link ecological and social outcomes. Ecological Indicators, 2018, Vol. 85, Pages 1262-1272https://doi.org/10.1016/j.ecolind.2017.12.001

8. European Commission. The EU Biodiversity Strategy to 2020, European Commission, 2011, ISBN 978-92-79-20762-4

9. European Commission. EU Biodiversity Strategy for 2030 Bringing nature back into our lives, European Commission, 2020, COM/2020/380 final, Brussels

10. Parlamentul României. Codul Silvic, republicat în Monitorul Oficial, Partea I nr. 611 din 12 august 2015

11. Guvernul României. Hotărârea nr. 1081/2013 privind aprobarea Strategiei naționale și a Planului de acțiune pentru conservarea biodiversității 2014-2020, Publicat în Monitorul Oficial, Partea I nr. 55 din 22 ianuarie 2014

12. Guvernul României. Hotărârea nr. 739/2016 pentru aprobarea Strategiei naționale privind schimbările climatice și creșterea economică bazată pe emisii reduse de carbon pentru perioada 2016-2020 și a Planului național de acțiune pentru implementarea Strategiei naționale privind schimbările climatice și creșterea economică bazată pe emisii reduse de carbon pentru perioada 2016-2020. Publicat în Monitorul Oficial, Partea I nr. 831 din 20 octombrie 2016

13. Administrația Națională Apele Române. Planul Național de Management Bazinal actualizat 2016-2021,

14. http://arhiva.rowater.ro/dasiret/SCAR/Planul\%20de\%20management.aspx (accessed on 09/04/2021)

15. Ministerul Investițiilor și Proiectelor Europene. Programul Operaţional Infrastructură Mare (POIM) 2014-2020,

16. https://mfe.gov.ro/programe/autoritati-de-management/am-poim/ (accessed on 10/04/2021)

17. Ministerul Agriculturii și Dezvoltării rurale. Programul Național pentru Dezvoltare Rurală 2014-2020, https://www.pndr.ro/pndr-2014-2020.html (accessed on 11/04/2021)

18. Ministerul Agriculturii și Dezvoltării rurale. Fondul European Agricol pentru Dezvoltare Rurală, perioadă de programare financiară $\quad(2014 \quad$ 2020) https://portal.afir.info/content.aspx(accessed on 09/04/2021)

19. Direcția Generală de Pescuit - Autoritatea de Management pentru POPAM (DGP-AMPOPAM). Programul Operațional pentru Pescuit și Afaceri Maritime, https://www.ampeste.ro/(accessed on $11 / 04 / 2021$ )

20. Ministrul dezvoltării, lucrărilor publice și administrației. Programul Operațional Regional (POR) 2014-2020, https://www.fonduri-ue.ro/por-2014 (accessed on 10/04/2021)

21. Guvernul României. Hotărârea nr. 877/2018 privind adoptarea Strategiei naționale pentru dezvoltarea durabilă a României 2030, Publicat în Monitorul Oficial, Partea I nr. 985 din 21 noiembrie 2018.

22. https://www.footprintnetwork.org/our-work/ecological-footprint/ (accessed on 07/04/2021) 